\title{
A Colaboração Compositor-Intérprete na Reelaboração de Passagens Não-Idiomáticas no Violão
}

\author{
Sabrina Souza Gomes, Leonardo Loureiro Winter \\ Universidade Federal do Rio Grande do Sul |Brasil
}

Resumo: A pesquisa tem como objetivo a reelaboração de passagens não-idiomáticas em uma obra para violão solo através do processo colaborativo compositorintérprete. A obra escolhida, o Estudo no 10 para violão solo do compositor brasileiro Marcelo Rauta, apresenta passagens não-idiomáticas, tornando difícil ou impossível a execução fluente da obra. A identificação das passagens não-idiomáticas foi realizada por três violonistas e a autora do trabalho. A partir da identificação das passagens não-idiomáticas, estabeleceuse um processo colaborativo da autora com o compositor, com o objetivo de tornar o texto musical mais fluente e idiomático para o violão. Como resultado destacamos a importância do processo colaborativo na resolução de passagens não-idiomáticas, com a apresentação de uma nova edição musical que enriquece o repertório brasileiro de estudos para o instrumento.

Palavras-chave: Colaboração compositor-intérprete, Idiomatismo, Marcelo Rauta, Violão solo.

\begin{abstract}
The research aims to rework non-idiomatic passages in a solo guitar work through a collaborative composer-performer process. The chosen work, Study no 10 for solo guitar by Brazilian composer Marcelo Rauta, presents non-idiomatic passages, making it difficult or impossible to perform the work fluently. Three guitarists and the author made the identification of non-idiomatic passages. From the identification of non-idiomatic passages, a collaborative process was established by the author and the composer in order to make the musical text more fluent and idiomatic for the guitar. As a result, we highlight the importance of the collaborative process in resolving non-idiomatic passages by presenting a new musical edition that enriches the Brazilian repertoire of studies for the instrument.
\end{abstract}

Keywords: Collaboration composer-performer, Idiomatism, Marcelo Rauta, Guitar solo. 


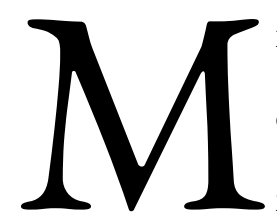
inha primeira experiência colaborativa com o compositor Marcelo Rauta1 foi no ano de 2013, através da construção da interpretação do Estudo no 5 para violão solo. Essa não foi a primeira experiência colaborativa do compositor. Pelo fato de não executar violão, Rauta estabeleceu relações de colaboração com outros intérpretes violonistas, nas quais trabalhou a reelaboração de passagens não-idiomáticas, omissões de trechos impraticáveis, escolha de possíveis digitações, e a construção de ideias interpretativas de suas obras (VIEIRA, 2017, p. 66). A tabela abaixo contém as obras para violão de Rauta que foram revisadas:

TABELA 1 - Obras para violão de Marcelo Rauta e violonistas revisores.

\begin{tabular}{ccc}
\hline Obra & Violonista Revisor & $\begin{array}{c}\text { Ano de Composição e de } \\
\text { Revisão }\end{array}$ \\
Suite Chaves & Átila de Carvalho e Renan Simões & 2005 \\
Sonatina no 1 & Roberto Velasco & 2005 \\
Prelúdio e Fuguetta no 1 & Humberto Amorim & 2009 \\
Sonata Nostálgica & Bruno Soares & 2010 \\
Rerigtiba & Bruno Soares & 2010 \\
Bach-Atiliana & Bruno Soares & 2010 \\
Preludio e Fuguetta no 2 & Renan Simões e Nicolas Barros & 2012 \\
Sonatina no 2 & Renan Simóes & 2012 \\
Fantasia & Renan Simões & 2014 \\
Doze Estudos & Renan Simóes & 2016 \\
Cinco Prelúdios & Moacyr Teixeira Neto & 2016 \\
& & \\
\hline
\end{tabular}

Fonte: GOMES (2018, p. 14)

O compositor pontua a importância desses processos colaborativos, citando como exemplo a revisão de sua primeira obra para violão solo, Suite Chaves':

\footnotetext{
${ }^{1}$ Marcelo Rauta é professor do Instituto Federal Fluminense, Doutor em Música (Educação Musical) pela UNIRIO, Mestre em Música (Composição) pela UFRJ e Bacharel em Música (Composição) pela mesma instituição. Suas obras têm sido executadas em importantes salas de concertos no Brasil, Alemanha, Argentina, Áustria, Chile, Estados Unidos, Itália, Portugal, República Tcheca e Uruguai. Como compositor possui obras premiadas em concursos tais como o Concurso Internacional Terceras Jornadas Internacionales de Formación Musical; Concurso Nacional de Composição para Orquestra de Câmara; Prêmio SESI Minas de Cultura; Concurso de Composição Niemeyer, Concurso Quintanares de Quintana em comemoração aos 100 anos de nascimento do poeta Mário Quintana e Concurso Nacional de Composição Cláudio Santoro, categoria coro e orquestra sinfônica - entre outros. Suas obras são publicadas pela Editora Periferia Sheet Music com sede em Barcelona, Espanha, e pela Academia Brasileira de Música, com sede no Rio de Janeiro, Brasil.

${ }^{2}$ Inicialmente intitulada Suite Miniaturinhazinhas.
} 
Minha primeira obra [Suite Chaves] para violão [solo] data de 2005 e neste ano não fazia ideia de como funcionava o instrumento. Foi importante a contribuição do violonista Roberto Velasco, o primeiro que me pediu obras para violão e que atentamente tocou trecho a trecho do que escrevi, de modo que aos poucos colocamos todas as minhas ideias 'na mão'. Não foi um processo imposto e de coautoria, aliás como todos os violonistas que revisaram as minhas obras até hoje [...]. A primeira versão foi revisada pelo violonista Átila de Carvalho, que recebeu homenagem de minha parte em outra obra, a Bach-Atiliana. A segunda versão, mais clara e mais exequível, teve a ajuda de Renan Simóes ${ }^{3}$ e ganhou até outro nome: Suite Chaves [...]. Não tive dificuldades com respeito ao processo colaborativo, só benefícios, principalmente de aprendizado. (VIEIRA, 2017, p. 263) .

O mesmo processo colaborativo ocorreu com os Doze Estudos ${ }^{5}$ para violão solo (os quais foram revisados pelo violonista Renan Simóes), com a exceção do Estudo no 10, que ainda não havia sido submetido a um processo de revisão minuciosa. Por essa razão, e pelo fato de ainda não ter sido interpretada, busquei analisar a obra a fim de investigar se havia a possibilidade de executá-la sem maiores complicações técnicas. Após a primeira análise, identifiquei passagens não-idiomáticas, fato que motivou meu interesse de pesquisa e, já que havia a possibilidade de trabalhar diretamente com o compositor, considerei a colaboração com Rauta uma oportunidade de reelaborar essas passagens, contribuindo assim com o acréscimo de uma obra revisada para a literatura brasileira do violão.

\section{Características da escrita idiomática e o violão}

Scarduelli (2007) conceitua o termo idiomatismo de forma objetiva, exemplificando os recursos que abrangem as possibilidades sonoras e/ou efeitos próprios da execução de um determinado instrumento. Para o autor, idiomatismo:

refere-se ao conjunto de peculiaridades ou convençốes que compõem o vocabulário de um determinado instrumento. Estas peculiaridades podem abranger desde características relativas às possibilidades musicais, como timbre, dinâmica e articulação, até meros efeitos que criam posteriormente interesse de ordem musical. Sendo assim, pode-se dizer que o idiomatismo refere-se a um recurso específico que é próprio de um instrumento musical, e idioma, o conjunto de idiomatismos que caracterizam a sua execução. (SCARDUELLI, 2007, p. 8).

\footnotetext{
${ }^{3}$ Vide referências: Simões (2016a) e Simões (2016b).

${ }^{4}$ Entrevista concedida a Vieira em 2015. (VIEIRA, 2017, p. 263).

${ }^{5}$ Os Estudos no 1 a no 7 foram compostos em 2012; os de no 8 a no 11 em 2015; e o Estudo no 12 em 2016. Alguns deles foram dedicados a violonistas de seu convívio, A saber: Estudo no 1 - Phillip Areias; Estudo no 2 - Caio Rodrigues; Estudo no 3 - Eliseu Martins; Estudo no 4 - Renan Simóes; Estudo no 5 - Sabrina Souza; Estudo no 6 - Bruno Soares; Estudo no 7 - Danilo Mota; Estudo no 12 - Márlou Peruzzolo Vieira.
} 
Sobre a escrita idiomática, Tullio (2005, p. 299) aponta que quanto maior é o aproveitamento das peculiaridades do instrumento, maior o nível de idiomatismo presente em uma obra. Desdobrando esse conceito inicial, destacamos os pontos levantados por Borém (2000, p. 96), o qual discorre acerca das sensações físicas e psicológicas que um intérprete vivencia ao interpretar uma obra idiomática: (1) exequibilidade; (2) conforto na sua realização; (3) satisfação; (4) e consequente maior interesse do público. Em outras palavras, Pereira \& Gloeden (2012, p. 530) utilizam os termos ergonômicos e naturais para qualificarem os movimentos mecânicos de uma obra tecnicamente confortável. Já Kreutz (2014, p. 106) pondera, além das questôes concernentes ao domínio psicomotor do intérprete, a possibilidade de se atingir um bom resultado sonoro na interpretação de obras com escrita idiomática. De outra forma, uma obra considerada não-idiomática pode causar "desgaste ao intérprete durante sua preparação, já que pode ser que este sinta suas energias desperdiçadas com trechos que nunca soarão do jeito que a escrita musical pede” (ALVIM, 2012, p. 61). Assim, o idiomatismo característico de uma determinada obra pode ser consequência do aproveitamento das potencialidades do instrumento, por meio das quais se obtém maior exequibilidade técnica e musical. Essa propriedade possibilita ao intérprete conforto psicomotor, visto que os movimentos mecânicos refletem a organicidade presente na construção da música.

Sobre a composição de obras para violão, os compositores Hector Berlioz, Alberto Ginastera, Stephen Dodgson, Richard Bennett, Ronaldo Miranda e Ricardo Tacuchian, declararam, em algum momento de suas carreiras, que sentiram dificuldade nessa experiência (VIEIRA, 2017, p. 29). Há uma consonância entre compositores não violonistas de que uma compreensão mais aprofundada sobre o instrumento - ou seja, o conhecimento de elementos próprios do universo do intérprete - é de fundamental importância para que se obtenha o idiomatismo na escrita musical. Isso se dá pelas características do próprio instrumento, dentre elas a possibilidade de realizar uma mesma nota em diferentes regiões da escala do violão, como mostra a FIGURA 1 abaixo ${ }^{6}$ :

\footnotetext{
${ }^{6} \mathrm{Na}$ FIGURA 1 as cordas do violão são representadas pelos números evidenciados por círculos e as casas/posições do braço do violão são representadas pelos números romanos.
} 
FIGURA 1 - Possibilidades de digitação referentes à nota $\mathrm{Mi}^{7}$ no violão.

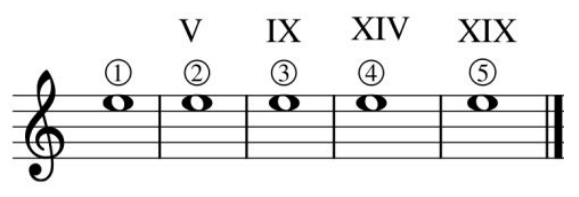

Fonte: GOMES (2018, p. 24)

Pereira \& Gloeden (2012, p. 526) mencionam que posições de mão esquerda com grandes distensões ${ }^{8}$, contraçốes de mão esquerda ${ }^{9}$, saltos muito grandes de uma região para a outra, e pestanas ${ }^{10}$ de longa permanência, podem ser configuradas como não-idiomatismos do violão. Esses conhecimentos, como nos aponta Vieira (2017, p. 33), podem ser oportunizados ao compositor por meio da colaboração com intérpretes, a qual vem sendo utilizada como um meio importante de troca de informações pertinentes a ambos os lados.

\section{Colaboração entre intérpretes e compositores e suas modalidades}

Borém (1998, p. 19) sugere que uma negociação saudável entre intérpretes e compositores é o resultado da busca simultânea pela satisfação de ambas as partes. Da mesma forma, Hansen (2016, p. 145, tradução nossa $)^{11}$ afirma que atitudes interpessoais positivas são componentes-chaves para que se atinja esse fim, dentre as quais: comunicação clara, honesta e detalhada entre os participantes, além do estabelecimento de conexôes pessoais entre os agentes, e alto nível de comprometimento dos envolvidos. Assim, o ato de colaborar compreende a habilidade de nos comunicarmos com o outro de forma clara e honesta, no diálogo sobre os possíveis antagonismos do processo. Desse modo, é possível estabelecer conexôes interpessoais produtivas, cujos modelos de colaboração a serem estabelecidos se darão a partir dos mais diversos contextos, motivaçôes e capacidades individuais dos participantes.

\footnotetext{
${ }^{7}$ O presente trabalho adota o Dó central como Dó4 (sistema norte americano).

${ }^{8}$ A palavra distensão refere-se ao movimento de abertura entre os dedos.

${ }^{9}$ A palavra contração refere-se ao movimento de aproximar os dedos uns dos outros.

${ }^{10}$ Segundo Madeira (2013) pestana pode ser definida como "qualquer situação na qual um dedo da mão esquerda pressiona a(s) corda(s) com outra parte que não seja a gema” (MADEIRA, 2013, p. 183).

11 "Some of the key components of positive interpersonal relationships include: (1) clear, honest, and detailed communication between the agents; (2) the establishment of personal connections between the agents; (3) a high level of commitment on the part of all of the agents" (HANSEN, 2016, p. 145).
} 
$\mathrm{Na}$ revisão dos trabalhos acadêmicos sobre colaboração, observamos relatos sobre a criação de novas obras ${ }^{12}$ e estudos, que discutem tanto a revisão da obra, como o processo de construção interpretativa em parceria com o compositor ${ }^{13}$. Da mesma forma, Vieira $(2015$, p. 817, tradução nossa $)^{14}$ aponta duas modalidades de colaboração que vêm se desenvolvendo ao longo do século XX: a colaboração direta durante o processo de composição, e a revisão da partitura após o processo de composição. De outro modo, Hayden \& Windsor (2007, p. 33) definem as modalidades de colaboração a partir do grau de interatividade entre compositores e intérpretes. Os autores apresentam três categorias que abrangem os diversos contextos colaborativos: a diretiva, a interativa e a colaborativa. $\mathrm{Na}$ diretiva, a hierarquia tradicional entre compositores e intérpretes é mantida, e o compositor determina a performance através das indicaçóes na partitura; na interativa, os intérpretes tem maior liberdade em relação ao texto musical, ainda que o compositor seja reconhecido como o único autor da obra; já na colaborativa não há um único autor ou hierarquia de papéis, ou seja, ambos partilham igualmente da posição de autoria.

Sobre as funções que os intérpretes podem desempenhar nas colaborações com os compositores, Beal \& Domenici (2014, p. 1) afirmam que o intérprete pode ser encomendador, executante, cocriador, e/ou consultor da obra. Essas categorias foram associadas às fases anterior, no decorrer, e posterior ao processo de composição. Segundo as autoras, no momento anterior à criação de uma obra, o intérprete pode desempenhar o papel de encomendador; quando a obra está sendo composta, tem os papéis de consultor e de cocriador; e após a obra completa, os papéis de consultor e de executante. A partir dessas informações, podemos considerar que os níveis de intervenção do intérprete em relação à partitura, os tipos de funções desempenhadas pelo intérprete, e as fases de criação da obra, são particularidades que delineiam padrões de colaboração. A depender das condições originadas desses aspectos, podem se configurar colaborações cujo nível de intervenção do intérprete é menor, moderado ou maior. Na TABELA 2 observamos, de forma resumida, possíveis relações

\footnotetext{
${ }^{12}$ Vide referências: Azevedo (2017), Scarduelli \& Ribeiro (2016), Marques (2015), Radicchi (2014) e Campbell (2012).

${ }^{13}$ Vide referências: Silva (2017), Silva (2015) e Ramos (2013).

14 "1) the direct collaboration during the composition process and 2) the revision of the score after the composition process” (VIEIRA, 2015, p. 817).
} 
entre as ideias dos autores citados ${ }^{15}$.

TABELA 2 - Interpretação sobre as modalidades de colaboração por Hayden e Windsor (2007), e funções exercidas pelos intérpretes apontadas por Beal \& Domenici (2014).

\begin{tabular}{cccc}
\hline $\begin{array}{c}\text { Modalidades de } \\
\text { Colaboração }\end{array}$ & $\begin{array}{c}\text { Níveis de intervenção do } \\
\text { intérprete }\end{array}$ & $\begin{array}{c}\text { Funçóes exercidas pelos } \\
\text { intérpretes }\end{array}$ & $\begin{array}{c}\text { Fases de composição } \\
\text { da obra }\end{array}$ \\
\hline Diretiva & Baixo & Executante & Depois \\
& Moderado & Executante & Antes \\
Interativa & Encomendador & Depois \\
& & Consultor & Antes \\
Colaborativa & Alto & Executante & Durante \\
& & Encomendador & Consultor \\
\hline
\end{tabular}

Fonte: GOMES (2018, p. 36)

Vale também destacar que a relação do intérprete com a partitura foi sendo ressignificada na última década, a partir do pensamento de que "não é possível extrair a identidade de uma obra musical tendo apenas como referência sua partitura” (INGARDEN, 1986, p. 34, tradução nossa) ${ }^{16}$ e que, portanto, há uma incompletude inerente ao texto musical. Ademais, o surgimento de novas técnicas instrumentais no século XX uniu intérpretes e compositores em um processo mútuo de novas descobertas (DOMENICI, 2012b, p. 79). Neste cenário, a prática colaborativa entre intérprete e compositor contribuiu para o "resgate dos aspectos social, material e humano da criação musical", além do reestabelecimento da "contiguidade entre o fenômeno sonoro e a notação" (DOMENICI, 2012b, p. 66). Em síntese, a colaboração compositor-intérprete torna-se, nessa nova etapa, substancial para o delineamento de novos caminhos, favorecendo o estreitamento dos laços entre intérpretes e compositores, e a escrita de obras idiomáticas, sobretudo nos casos em que os compositores não dominam o instrumento:

\footnotetext{
${ }^{15}$ Cada evento de colaboração é único, e por isso não pretendemos com essa reflexão atribuir conceitos fixos às diversas possibilidades de colaboração existentes. Não obstante, notamos que a utilização de categorias pode servir como um meio didático de esclarecer e avançar o conhecimento sobre os fatores que podem construir uma comunicação produtiva entre intérpretes e compositores.

16 "It is not [...] possible to bring about the identification of a musical work with its score" (INGARDEN, 1986, p. 34).
} 
Obras mais idiomáticas têm sido escritas devido à intensificação da relação entre intérpretes e compositores, principalmente. Segundo Borém (2000), uma avaliação do resultado sonoro da partitura diretamente com o intérprete [...] ainda é ferramenta mais útil no processo de confirmar, refinar ou excluir partes da escrita imaginada pelo compositor [...]. Muitos compositores apresentam em suas obras aspectos idiomáticos devido a três motivos: por tocarem o instrumento, pela experiência de composiçóes anteriores ou pela aproximação com os instrumentistas. (TULLIO, 2005, p. 300).

\section{Metodologia}

No processo de construção interpretativa do Estudo no 10, registrei em diários de estudo minha experiência individual com a obra, a partir da qual destaquei passagens que classifiquei como nãoidiomáticas. Com o objetivo de atestar esta observação, submeti a edição original ${ }^{17}$ do Estudo no 10 à avaliação de três violonistas ${ }^{18}$ que estudaram a obra por uma semana ${ }^{19}$. A coleta desses dados se deu por meio de entrevistas semiestruturadas ${ }^{20}$, a partir das quais organizei minhas sugestóes de modificação em relação à edição original em temas e subtemas, tendo como base tanto o cruzamento das informações obtidas na consulta aos violonistas participantes, quanto as informaçôes registradas a partir do meu estudo individual da obra. López-Cano \& Cristóbal (2014) nos esclarecem sobre esse procedimento metodológico:

Nesse formato dispensamos a organização cronológica das ações na linha do tempo e nos
concentramos no reconhecimento e na sistematização de ações concretas
independentemente de sua ordem cronológica. Durante certo período de tempo (um ou
vários dias, uma ou várias semanas, um ou vários meses, etc.), registramos as ações artísticas
que foram feitas e realizamos uma contagem ou inventário delas. Em seguida, analisamos
como elas se relacionam e como podem ser organizadas em uma estrutura conceitual
coerente. Então podemos classificar as ações criando categorias e subcategorias: ações
relacionadas, similares, redundantes, complementares, opostas, derivativas, etc. (LÓPEZ-

\footnotetext{
${ }^{17}$ Vide edição original do Estudo no 10 no Apêndice 1.

${ }^{18}$ A escolha dos participantes se deu pelo nível de expertise dos mesmos, ou seja, pelas habilidades técnicas e conhecimento do repertório de violão.

${ }^{19}$ As partituras disponibilizadas aos violonistas participantes não continham digitações ou anotações quaisquer sobre a obra.

${ }^{20}$ As entrevistas foram gravadas em áudio e vídeo.
} 
CANO \& CRISTÓBAL, 2014, p. 155, tradução nossa $)^{21}$.

$\mathrm{Na}$ análise dos dados das entrevistas realizadas com os violonistas, identifiquei que, ao serem perguntados sobre quais passagens do Estudo no 10 consideraram idiomáticas, difíceis e/ou nãoidiomáticas, observei no discurso dos participantes que os mesmos se referiram aos seguintes conceitos:

- Passagens não-idiomáticas são aquelas impossíveis de serem executadas;

- Passagens de dificuldade técnica extrema são assim classificadas por conterem características que apenas serão resolvidas com muito tempo de estudo, mas que, mesmo assim, podem continuar gerando desconforto;

- Passagens de dificuldade técnica usual são aquelas cuja familiaridade técnica depende de um pouco mais de tempo de estudo;

O contato com o compositor se processou em três momentos distintos: na entrevista inicial, no processo de colaboração, e na entrevista final. $\mathrm{Na}$ entrevista inicial, compartilhei com Rauta minhas intençôes com relação ao processo de colaboração, e obtive o ponto de vista do compositor sobre os conceitos de idiomatismo e colaboração compositor-intérprete ${ }^{22}$. O processo de colaboração se deu à distância já que, nessa época, Rauta residia na Itália, e eu, no Brasil. Com o intuito de transpor essa dificuldade, registrei e detalhei em vídeos, fotos e textos minhas sugestões de modificação para cada passagem do Estudo no 10 classificada como não-idiomática, de dificuldade técnica extrema, ou usual - o que resultou em nove etapas de colaboração, cada qual motivada por questóes de mão

\footnotetext{
21 "En este formato prescindimos de la organización cronológica de las acciones en la línea de tiempo y nos concentramos en el reconocimiento y sistematización de acciones concretas independientemente de su orden cronológico. Durante un intervalo de tiempo determinado (uno o varios días, una o varias semanas, uno o varios meses, etc.), registramos las acciones artísticas que hacemos y realizamos un recuento o inventario de ellas. Luego analizamos cómo se relacionan entre ellas y cómo se pueden organizar en una estructura conceptual coherente. Entonces podemos clasificar las acciones creando categorías y subcategorías: acciones relacionadas, similares, redundantes, complementarias, opuestas, derivadas, etc. Esto nos informa sobre cómo se plantean y resuelven determinados problemas vinculados con la creación" (LÓPEZCANO; CRISTÓBAL, 2014, p. 155).

22 "Eu acho tudo muito relativo, o que é idiomático, o que pode funcionar, o que pode não funcionar; muitas coisas que eram consideradas como não-idiomáticas durante uma época, depois de um tempo, com o uso e com a prática, com as tentativas, passaram a ser idiomáticas. Então [...] o conceito muda. De época para a época, de estética para estética, de estilo para estilo, de compositor para compositor. [...] Se um [intérprete] conseguiu já deixa de ser impossível; pode ser não tão fácil, ou tão acessível” (GOMES, 2018, p. 111).
} 
esquerda, mão direita, indicação de andamento e uma única passagem impossível de ser executada, conforme mostra a TABELA 3 abaixo:

\begin{tabular}{ccc} 
TABELA 3 - Passagens do Estudo no 10 que foram trabalhadas nas etapas colaborativas com o composit \\
respectivas causas apresentadas \\
\hline Etapas de Colaboração & Compassos & Causas \\
\hline 1 & $9,13,49$ e 53 & Abertura de mão esquerda \\
2 & $9-10,13-14,49-50$ e $53-54$ & Abertura de mão esquerda \\
3 & 20 e 60 & Abertura de mão esquerda \\
4 & 11,51 e 55 & Impossibilidade \\
5 & 1 e 2 & Abertura de mão direita \\
6 & 27 & Abertura de mão direita \\
7 & 36 & Abertura de mão direita \\
8 & 38 & Abertura de mão direita \\
9 & 22 a 48 & Andamento \\
\hline
\end{tabular}

Fonte: GOMES (2018, p. 50).

Esses registros foram enviados ao compositor via e-mail, nos quais anexamos arquivos word contendo os textos, fotos, e links dos vídeos produzidos para o processo colaborativo. Da mesma forma, sugeri a Rauta que registrasse seus comentários sobre cada etapa de colaboração nos arquivos enviados. Ao final, revisamos as etapas desse processo em conversa por videoconferência, discutindo a opção final para cada sugestão de modificação do texto original. A entrevista final foi pautada por questóes acerca do ponto de vista do compositor sobre o formato de colaboração compositorintérprete adotado.

\section{Resultados}

Detalhamos a seguir, um compilado dos resultados obtidos nas etapas colaborativas a partir das informações coletadas na interlocução com os violonistas, do contato individual com a obra, e da colaboração com o compositor. Esses resultados foram organizados em passagens não-idiomáticas, de dificuldade técnica extrema, e de dificuldade técnica usual ${ }^{23}$.

\footnotetext{
${ }^{23}$ As diversas possibilidades de digitações e modificaçôes de cada passagem abordada foram esmiuçadas para que o compositor compreendesse as vantagens e desvantagens do ponto de vista técnico e interpretativo. Para maiores informaçốes, vide GOMES (2018).
} 


\subsection{Passagens não-idiomáticas}

Os violonistas participantes apontaram nas entrevistas a impossibilidade de se executar o primeiro acorde do compasso 11 (FIGURA 2), para o qual cada um sugeriu como alternativa: 1) omitir o Ré; 2) acrescentar o Mi e omitir o Ré; 3) ou substituir o Ré pelo Lá.

FIGURA 2 - Estudo no 10 para violão solo de Marcelo Rauta, edição original, compasso 11.

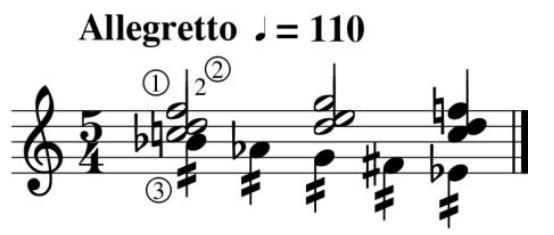

Fonte: GOMES (2018, p. 16)

Essa questão foi abordada na quarta etapa colaborativa, na qual, dentre as diversas possibilidades que foram cogitadas e detalhadas para o compositor, sugeri que o Dó fosse omitido e o Mi fosse acrescentado, mantendo o Sib da melodia (FIGURA 3). Sobre essa possibilidade, apontamos para o compositor que, apesar de ser menos confortável tecnicamente e trazer maior instabilidade para a mão esquerda, a mesma promove o ganho de ressonância do acorde no contexto da passagem, correspondendo às expectativas sonoras concebidas originalmente ${ }^{24}$.

FIGURA 3 - Estudo no 10 para violão solo de Marcelo Rauta, compasso 11, sugestão de modificação.

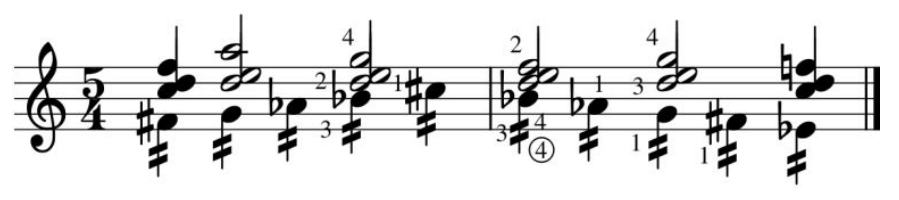

Fonte: GOMES (2018, p. 88)

Rauta aponta sua preferência para manter o acorde constituído das notas Fá, Ré e Dó e destaca que "a construção da composição é dada pela sequência do acompanhamento e a melodia foi criada para 'acompanhar' o acompanhamento, é o pensamento contrário [...] foi uma criação inversa”

\footnotetext{
${ }^{24}$ Disponível em: <https://youtu.be/JVNhWEsRIQU>. Acesso em: 01 set. 2020.
} 
(GOMES, 2018, p. 89) 25 . Dessa forma, manter os intervalos de 2a e $4^{\underline{a}}$ seria mais importante do que manter o Sib, que constitui a melodia em tremolo. Por fim, essa passagem foi solucionada após o compositor ponderar todas as possibilidades, e sugerir, além da omissão do Dó e acréscimo do Mi, manter o acorde original constituído das notas Fá-Ré-Dó-Si b, substituindo o Sib da melodia pelo Sol $(\text { FIGURA } 4)^{26}$.

FIGURA 4 - Estudo no 10 para violão solo de Marcelo Rauta, compassos 10 e 11, resultado da colaboração.

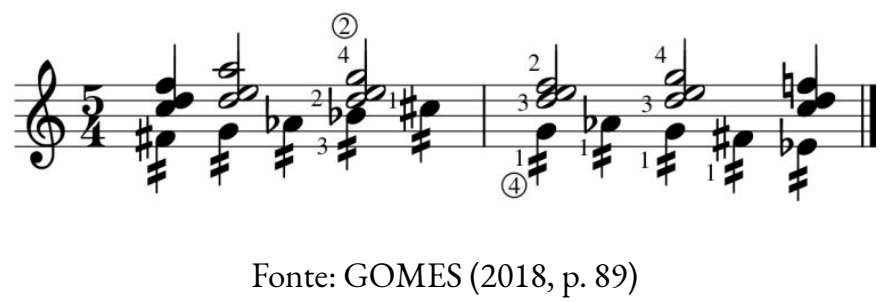

\subsection{Passagens de dificuldade técnica extrema}

Os violonistas destacaram que a subdivisão de quatro notas do tremolo da parte B é difícil de ser realizada no andamento indicado (FIGURA 5), na qual atingiram o andamento máximo de 44 BPM.

FIGURA 5 - Estudo no 10 para violão solo de Marcelo Rauta, edição original, compasso 24, andamento estipulado pelo compositor.

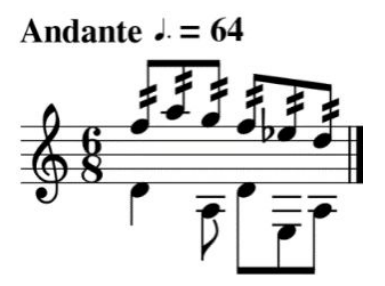

Fonte: GOMES (2018, p. 107)

Como alternativa para essa passagem, os participantes indicaram que, subdividir as notas de melodia em três ao invés de quatro, poderia atenuar a dificuldade técnica. Essa questão foi abordada na nona etapa colaborativa, para a qual essas informações concedidas pelos violonistas foram de

\footnotetext{
${ }^{25}$ Entrevista concedida por Marcelo Rauta em 2018.

${ }^{26}$ Disponível em: <https://youtu.be/5dJVXucIgpw>. Acesso em: 01 set. 2020.
} 
extrema importância, principalmente no momento de apresentarmos evidências ao compositor sobre as sugestóes que oferecem ganhos ou perdas na execução da passagem.

Desse modo, destaquei para Rauta que é incomum, para os violonistas de modo geral, realizarem um tremolo contínuo em compasso composto binário, onde cada colcheia da melodia se desdobra em quatro. Nesse caso, o polegar e o anelar tocam, ao mesmo tempo, o baixo e a primeira nota da melodia, resultando na combinação de dedos da mão direita grafada na FIGURA 6, o que dificulta bastante a execução veloz do tremolo ${ }^{27}$ :

FIGURA 6 - Estudo no 10 para violão solo de Marcelo Rauta, edição original, compasso 24, tremolo escrito por extenso.

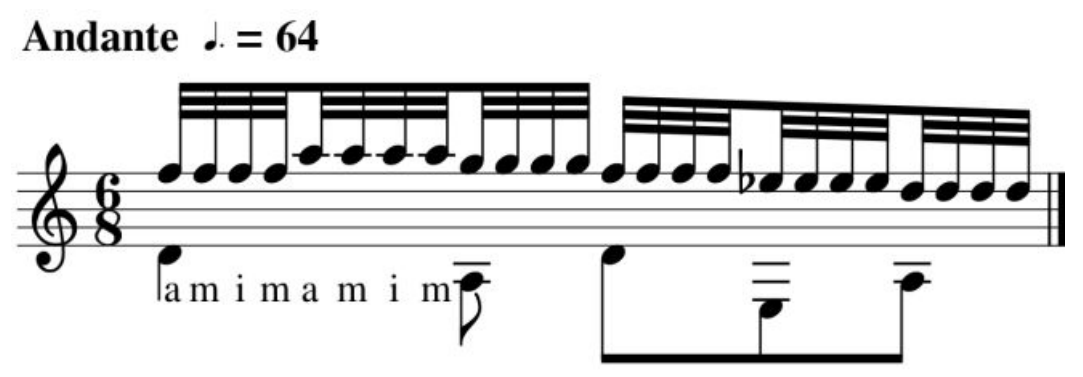

Fonte: GOMES (2018, p. 107)

Também ponderamos que, em geral, encontramos no repertório para violão o tremolo em compasso quaternário, onde primeiro toca-se o baixo e em sequência as demais notas, que podem ser executadas com a combinação de dedos $\mathrm{p}-\mathrm{a}-\mathrm{m}$ - i da mão direita, conforme mostra a FIGURA 7 abaixo:

FIGURA 7 - Exemplo de tremolo usual na escrita para violão.

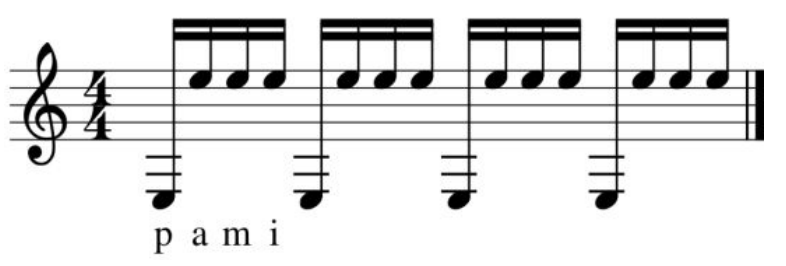

Fonte: GOMES (2018, p. 107)

Desse modo, dentre as diversas possibilidades sugeri ao compositor modificar a subdivisão do tremolo

\footnotetext{
${ }^{27}$ Disponível em: < https://youtu.be/Nkm2fVW6Vws $>$. Acesso em: 01 set. 2020.
} 
de quatro para duas notas, o que nos permite tocar o trecho no andamento de 64 BPM sendo, ainda possível, aumentar o andamento para $75 \mathrm{BPM}$, ou até $84 \mathrm{BPM}^{28}$. A partir dessas colocaçóes, Rauta concordou com essa alternativa, ressaltando ser esta a que mais se aproxima de sua ideia original, conforme mostra a FIGURA 8 abaixo:

FIGURA 8 - Estudo no 10 para violão solo de Marcelo Rauta, compassos 24 e 25, sugestão de modificação.

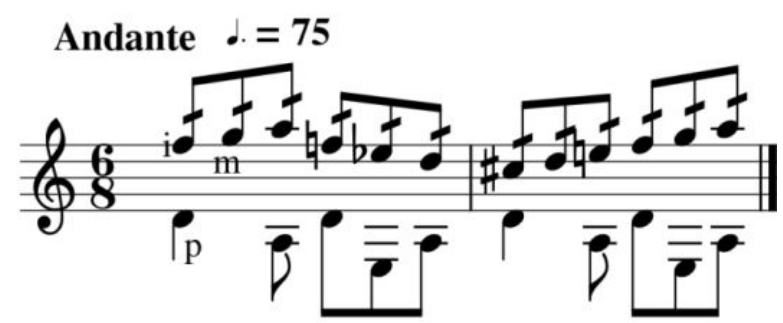

Fonte: GOMES (2018, p. 110)

\subsection{Passagens de dificuldade técnica usual}

Os violonistas apontaram que, em função do andamento solicitado pelo compositor, há dificuldade em atingir fluência no discurso musical e, para tal, sugerem a adição de indicaçôes de rallentando em pontos específicos da obra. Da mesma forma, ao entrever essa questão, Rauta sugere, na primeira e terceira etapas colaborativas, indicações de rallentando, sendo essas acrescentadas no compasso 8 e no compasso 20.

$\mathrm{Na}$ primeira etapa de colaboração, detalhei para o compositor que a edição original do compasso 9 (FIGURA 9) apresenta uma abertura excessiva entre os dedos da mão esquerda (FIGURA 10), o que prejudica a sonoridade da passagem ${ }^{29}$.

\footnotetext{
${ }^{28}$ Disponível em: <https://youtu.be/HHj3X0K9lpU>. Acesso em: 01 set. 2020.

${ }^{29}$ Disponível em: <https://youtu.be/MFcjTq981mY>. Acesso em: 01 set. 2020.
} 
FIGURA 9 - Estudo no10 para violão solo de Marcelo Rauta, edição original, compasso 9, primeira possibilidade de digitação.

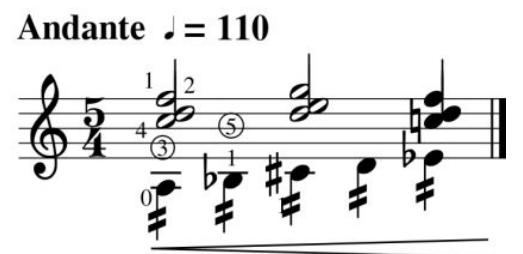

Fonte: GOMES (2018, p. 110)

FIGURA 10 - Estudo no 10 para violão solo de Marcelo Rauta, compasso 9, posição de mão esquerda da primeira possibilidade de digitação.

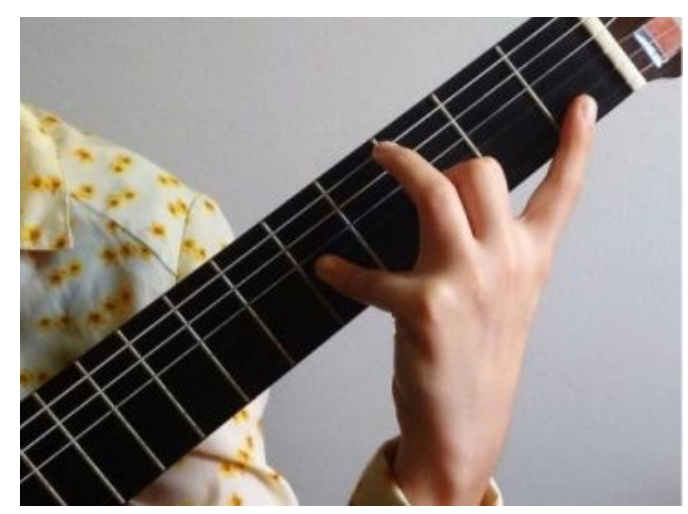

Fonte: GOMES (2018, p.61)

Sendo assim levantei a possibilidade de substituir o Dó pelo Lá, e o Ré pelo Sol (FIGURA 11), o que possibilitaria que a mão esquerda se mantivesse praticamente com a mesma apresentação na mudança de uma posição para outra (FIGURA 12) ${ }^{30}$.

FIGURA 11 - Estudo no 10 para violão solo de Marcelo Rauta, compasso 9, sugestão de modificação.

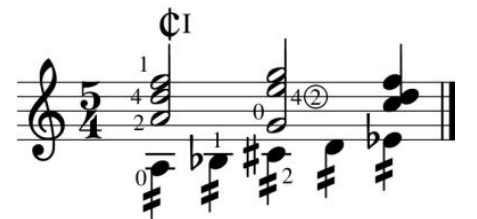

Fonte: GOMES (2018, p. 67)

\footnotetext{
${ }^{30}$ Disponível em: <https://youtu.be/N9WiaUaj9Dw>. Acesso em: 01 set. 2020.
} 
FIGURA 12 - Estudo no 10 para violão solo de Marcelo Rauta, compasso 9, apresentação da mão Esquerda
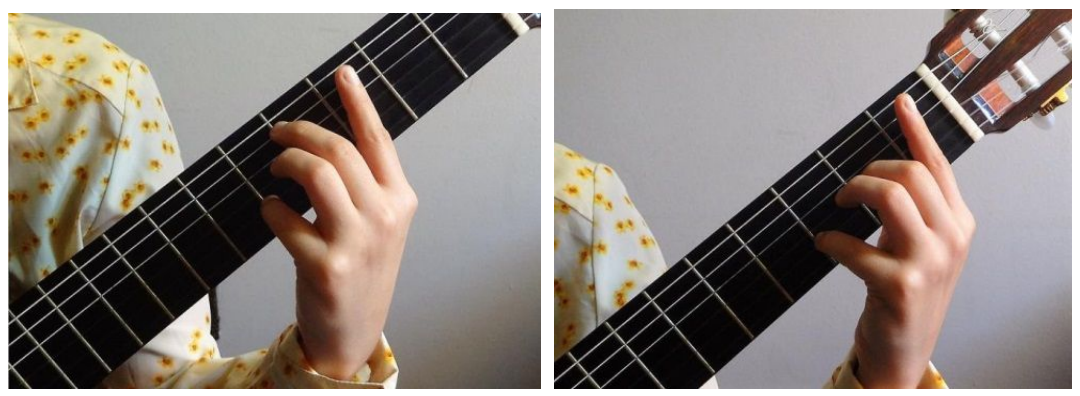

Fonte: GOMES (2018, p. 68)

Conforme comentado pelo compositor sobre essa passagem:

Realmente há uma abertura grande entre os dedos e a melodia sustentada pela nota Fá desaparece. Isso ocorre porque é uma abertura grande para a maioria dos violonistas ou somente no seu caso? Pergunto por que dependendo da situação poderíamos criar ossias e deixar as duas alternativas, caso ambas sejam possíveis. (GOMES, 2018, p. 68).

Expliquei que geralmente essa abertura é difícil para a maioria dos violonistas, e que nesse caso poderíamos colocar alternativas (ossias), embora dificilmente os violonistas optassem pela digitação da passagem na primeira posição. Destaquei também que todos os três violonistas consultados a digitaram na sexta posição, em vista do desconforto técnico gerado quando executada nas primeiras posições. Por fim, Rauta sugere substituir o Sol pelo Si ou Sib (FIGURA 13), afirmando que esse seria outro modo de manter a ideia original, dado que a opção "mantém a sequência de paralelismo dos dois acordes menores: Ré menor e Mi menor” (GOMES, 2018, p. 69). Além disso, chegamos à conclusão de que seria interessante escrever na partitura uma indicação de rallentando no compasso $8^{31}$.

FIGURA 13 - Estudo no 10 para violão solo de Marcelo Rauta, compasso 9, Resultado da colaboração.

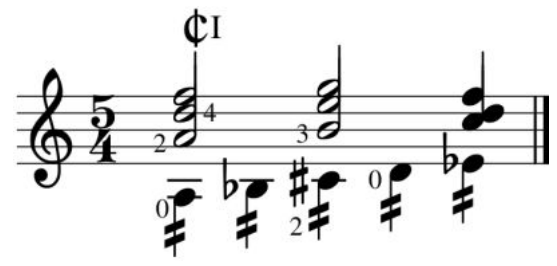

Fonte: GOMES (2018, p. 70)

\footnotetext{
${ }^{31}$ Disponível em: <https://youtu.be/VcNSNmhA3zg >. Acesso em: 01 set. 2020.
} 
$\mathrm{Na}$ terceira etapa colaborativa, após analisar as alternativas referentes ao compasso 20 (FIGURA 14), o compositor concordou que a mudança entre as posições de mão esquerda é abrupta e prejudica a sonoridade (GOMES, 2018, p. 82) ${ }^{32}$.

FIGURA 14 - Estudo no 10 para violão solo de Marcelo Rauta, compasso 20, edição original.

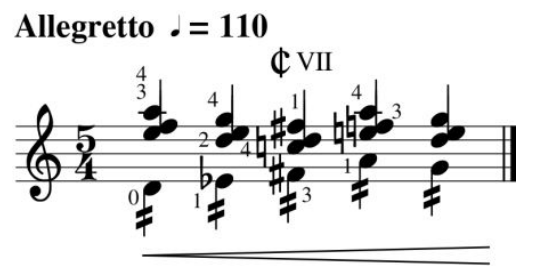

Fonte: GOMES (2018, p. 80)

A respeito dessa passagem, Rauta comenta que: "apesar do corte, na sequência inteira não observei uma sonoridade dura, nem mudanças tão bruscas” (GOMES, 2018, p. 82). Após refletir sobre esse comentário, repensei a real necessidade de modificar a passagem, mesmo tendo o consentimento do compositor. Na conclusão dessa etapa, Rauta propôs que a mantivéssemos como no original, incorporando ao texto uma indicação de rallentando.

Sobre as dif iculdades de mão direita, o violonista B destaca que essas ocorrem quando três vozes devem soar ao mesmo tempo, o que gera a necessidade de se realizar grandes aberturas entre os dedos. O participante não sugere modificaçôes específicas já que previu que, com o tempo de estudo da obra, talvez fosse possível executá-las. Porém, percebemos que seria interessante propor ao compositor algumas alternativas para essas passagens, as quais foram discutidas nas quinta, sexta, sétima e oitava etapas.

$\mathrm{Na}$ quinta etapa colaborativa comentei com o compositor que as aberturas de mão direita dos compassos 1 e 2 geram incômodo. Destaquei que, quando executado no andamento sugerido na partitura, esse trecho não flui tão organicamente, dada a combinação do tremolo executado com a sequência de dedos $\mathrm{a}-\mathrm{m}-\mathrm{i}-\mathrm{m}^{33}$, onde tocamos o polegar juntamente com o anelar, conforme explicitado na FIGURA $15^{34}$ :

\footnotetext{
${ }^{32}$ Disponível em: <https://youtu.be/G90RC9Og8IM>. Acesso em: 01 set. 2020.

${ }^{33}$ Anelar - médio - indicador - médio.

${ }^{34}$ Disponível em: <https://youtu.be/LfHdtsUDeXU>. Acesso em: 01 set. 2020.
} 
FIGURA 15 - Estudo no 10 para violão solo de Marcelo Rauta, compassos 1 e 2, edição original.

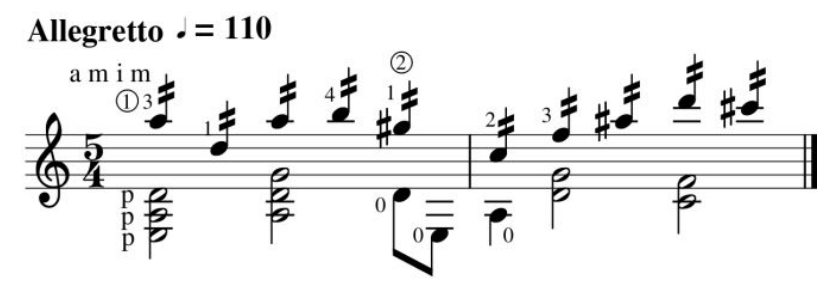

Fonte: GOMES (2018, p. 90)

Como alternativa, sugeri modificar a sequência dos baixos para Mi - Lá - Ré (FIGURA 16), o que permite ao violonista obter maior velocidade e precisão já que, nesse caso, realiza-se um único movimento do polegar para baixo que abrange essas três notas ${ }^{35}$. O compositor concordou com a sugestão apresentada destacando que essa alteração dos bordões apresenta uma sequência de quartas justas interessante (GOMES, 2018, p. 92).

FIGURA 16 - Estudo no 10 para violão solo de Marcelo Rauta, compassos 1 e 2, resultado da colaboração.

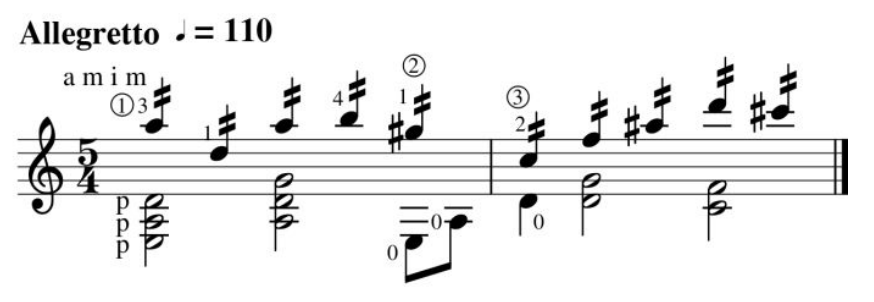

Fonte: GOMES (2018, p. 92)

Da mesma forma, na sexta etapa colaborativa apresentamos três aberturas incômodas de mão direita que ocorrem em sequência no compasso 27 (FIGURA 17). Expliquei ao compositor que, dado o rápido deslocamento dos dedos da mão direita, esse pequeno trecho, quando executado no andamento sugerido na partitura, também não flui organicamente ${ }^{36}$.

\footnotetext{
${ }^{35}$ Disponível em: <https://youtu.be/pPwitCVmwDE>. Acesso em: 01 set. 2020.

${ }^{36}$ Disponível em: <https://youtu.be/pPwitCVmwDE> . Acesso em: 01 set. 2020.
} 
FIGURA 17 - Estudo no 10 para violão solo de Marcelo Rauta, compasso 27, edição original.

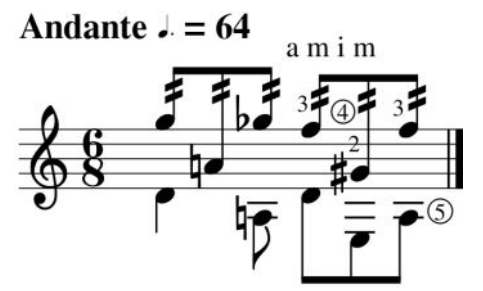

Fonte: GOMES (2018, p. 93)

Rauta concorda sobre a dificuldade exposta, e conclui que a melhor opção seria a inversão dos baixos (FIGURA 18) ${ }^{37}$. Porém, com ressalvas, sugere que essa opção seja acrescentada em forma de ossia, mantendo o trecho original que também é exequível. Ao reestudar a passagem, percebi que no meu caso faz bastante diferença tocar a passagem com a ordem dos baixos invertidos, e por isso optei por manter a ossia sugerida pelo compositor.

FIGURA 18 - Estudo no 10 para violão solo de Marcelo Rauta, compassos 1 e 2, sugestão de modificação.

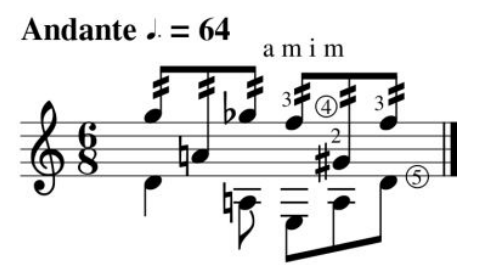

Fonte: GOMES (2018, p. 97)

Nessa etapa, o compositor também comenta que, caso tivéssemos optado pela sugestão de pinçar o Mi da sexta corda com a mão esquerda para liberar a mão direita de tocá-lo, haveria uma ressonância que ressalta o Sol\#, nota que não deveria ser destacada nessa sequência melódica ${ }^{38}$. Esse comentário trouxe um novo direcionamento para interpretação métrica da peça, cuja acentuação foi revisada na preparação para a performance final da obra ${ }^{39}$.

$\mathrm{Na}$ sétima etapa colaborativa, apresentei ao compositor o incômodo gerado pela abertura de mão direita entre os dedos indicador e anelar no compasso 35, conforme apresentado nas FIGURAS 19 e 20 abaixo $^{40}$.

\footnotetext{
${ }^{37}$ Disponível em: <https://youtu.be/Urk22Q62Ync>. Acesso em: 01 set. 2020.

${ }^{38}$ Disponível em: <https://youtu.be/7gvW8gqs3gE >. Acesso em: 01 set. 2020.

${ }^{39}$ Disponível em: <https://youtu.be/BAQm0-y24mA > . Acesso em: 01 set. 2020.

${ }^{40}$ Disponível em: <https://youtu.be/J5kVoaq-Yj4 > . Acesso em: 01 set. 2020.
} 
FIGURA 19 - Estudo no 10 para violão solo de Marcelo Rauta, compasso 34 e 35, edição original.

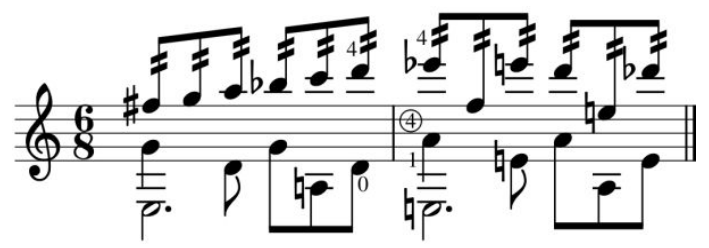

Fonte: GOMES (2018, p. 98)

FIGURA 20 - Estudo no 10 para violão solo de Marcelo Rauta, compasso 36, abertura de mão direita.

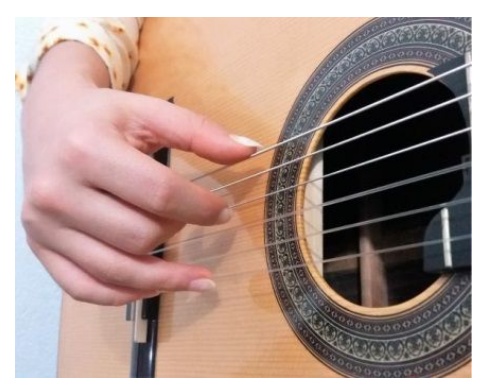

Fonte: GOMES (2018, p. 98)

Dentre as possibilidades apresentadas ao compositor, o mesmo concordou com a opção de oitavar o Lá(FIGURA 21), realizando um único movimento com o polegar para baixo para tocar o Mi e o Lá, o que não apresenta prejuízo em relação à técnica e ao resultado sonoro, e favorece o ganho de volume sonoro do instrumento ${ }^{41}$. Rauta comenta que essa alternativa não prejudica em nada sua ideia inicial (GOMES, 2018, p. 102).

FIGURA 21 - Estudo no 10 para violão solo de Marcelo Rauta, compassos 34 e 35, resultado da colaboração.

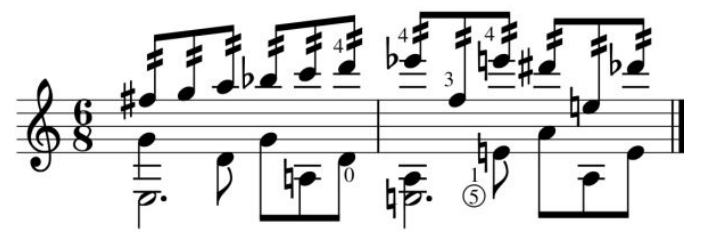

Fonte: GOMES (2018, p. 101)

$\mathrm{Na}$ oitava etapa colaborativa, apontamos da mesma forma uma abertura de mão direita incômoda entre os dedos polegar, indicador e anelar da mão direita, conforme apresentado nas FIGURAS $22^{42}$.

\footnotetext{
${ }^{41}$ Disponível em: <https://youtu.be/9a11EehD60k > . Acesso em: 01 set. 2020.

${ }^{42}$ Disponível em: <https://youtu.be/xjVsl1J7myU>. Acesso em: 01 set. 2020.
} 
FIGURA 22 - Estudo no 10 para violão solo de Marcelo Rauta, compasso 37 e 38, edição original.

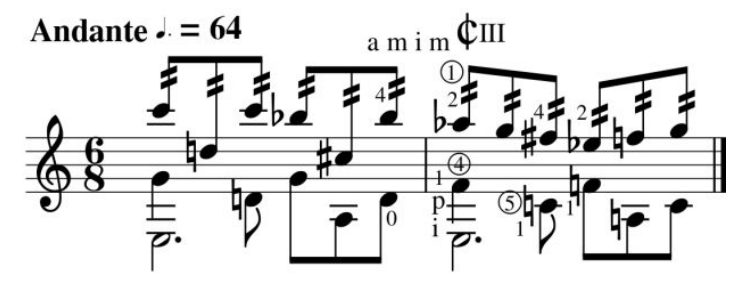

Fonte: GOMES (2018, p. 103)

Com objetivo de digitarmos a passagem na décima casa, sugerimos ao compositor oitavar o Dó (FIGURA 23), sendo possível eliminar deslocamentos de mão esquerda e aberturas incômodas de mão direita ${ }^{43}$.

FIGURA 23 - Estudo no 10 para violão solo de Marcelo Rauta, compasso 37 e 38, resultado da colaboração.

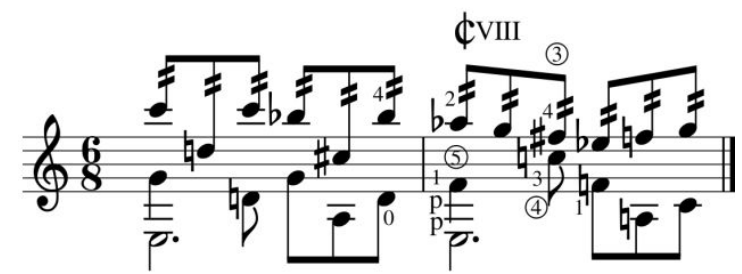

Fonte: GOMES (2018, p. 104)

O compositor concordou com a problemática apontada e deu seu parecer final: "Novamente a simplicidade de apenas oitavar uma nota não interfere em minha ideia inicial” (GOMES, 2018, p. 106).

\section{Discussão}

Avaliamos que os violonistas participantes apontaram necessidades parecidas com as quais foram levantadas inicialmente em meu processo de estudo individual da peça. No entanto, considerei a necessidade de sugerir ao compositor algumas alterações que não foram levantadas pelos participantes, as quais nos renderam resultados colaborativos interessantes nas quinta, sexta e sétima etapas colaborativas. Nesse sentido, destacamos a cautela dos três violonistas ao lidarem com questóes

\footnotetext{
${ }^{43}$ Disponível em: <https://youtu.be/G3zuKE8uuSU>. Acesso em: 01 set. 2020.
} 
referentes a passagens de dificuldade técnica usual ou de dificuldade técnica extrema, o que nos levou a concluir que, quanto maior é considerado o nível de idiomatismo identificado em uma determinada passagem - ou até mesmo quando se levanta a hipótese de que a passagem pode se tornar mais idiomática com o tempo de estudo -, menos sentiu-se a necessidade e a propriedade dos intérpretes de intervirem na edição original do compositor. Todavia, mesmo sendo relativamente idiomáticas, observamos que as alterações propostas para essas passagens promoveram, além de um debate repleto de informações importantes para a interpretação da obra, um melhor resultado técnico e sonoro sem que a ideia do compositor fosse adulterada.

$\mathrm{Na}$ entrevista inicial com Rauta perguntamos sobre a visão de idiomatismo do compositor e sua ideia a respeito da colaboração entre intérpretes e compositores. Sobre a primeira questão, Rauta aponta que, para ele, o idiomatismo é relativo, e por isso considera a possibilidade do conceito de idiomatismo de uma determinada obra ser alterado conforme o tempo passa, até que os intérpretes consigam executá-la sem maiores dificuldades:

Eu acho tudo muito relativo, o que é idiomático, o que pode funcionar, o que pode não funcionar; muitas coisas que eram consideradas como não-idiomáticas durante uma época, depois de um tempo, com o uso e com a prática, com as tentativas, passaram a ser idiomáticas. Então [...] o conceito muda. De época para a época, de estética para estética, de estilo para estilo, de compositor para compositor. [...] Se um [intérprete] conseguiu, já deixa de ser impossível; pode ser não tão fácil, ou tão acessível. (GOMES, 2018, p. 111).

Esse pensamento de Rauta pode ser observado quando o mesmo propõe a criação de ossias nas primeira e sexta etapas colaborativas, tendo em vista que, a depender do instrumentista que irá interpretar sua obra, a passagem original poderá ser executada sem dificuldades. Quanto à colaboração, o compositor considera que o intérprete é uma fonte de conhecimentos sobre os quais ele não tem domínio, e que esse contato com a performance dos instrumentistas o possibilita realizar e visualizar suas obras no plano concreto. Além disso, o compositor pontua sua intenção de tornar suas composições acessíveis à maioria dos instrumentistas, destacando que, a depender do bom senso do intérprete, as mudanças realizadas no texto musical não alteram sua ideia original:

Acho excelente, é uma maneira de você conseguir colocar sua ideia no papel, com o auxílio de um instrumentista que conhece toda a mecânica do instrumento, ainda mais quando você não toca o instrumento [...] A minha intenção sempre foi deixar [a obra] acessível à maioria; 
nunca pensei em fazer algo que só um ou dois conseguissem tocar. Se não, perde o objetivo da música e da arte, que é você fazer e divulgar sua música para todos [...]. É claro, se tem um problema [...] pode mudar uma nota [...] não vai fazer diferença alguma [...] na minha ideia [...] é óbvio que [...] não vai ser qualquer nota; você vai procurar uma nota que também se encaixe dentro do estilo da criação. (GOMES, 2018, p. 112).

Nas terceira, quinta, sétima, oitava, e nona etapas colaborativas, entrevemos esse pensamento de Rauta, ocasióes nas quais propus alteraçóes que foram vistas pelo compositor como possibilidades de tornar a obra mais acessível. Dessa forma, concluímos que o mesmo enxerga a possibilidade de parceria com o intérprete de sua obra e, portanto, se demonstra disponível para receber sugestóes de modificação nas suas ediçôes originais, principalmente quando a motivação dessas são amparadas pelo pensamento crítico e bom senso do intérprete, ou seja, desde que a subjetividade do idiomatismo musical seja levada em consideração no decorrer do processo de construção interpretativa da obra.

Rauta ainda expressa que não possui uma visão fechada da interpretação das peças que compóe, considerando que cada instrumentista obterá um resultado diferente. Para o compositor isso é motivo de contentamento, justamente por ter a oportunidade de observar os diversos significados que podem ser atribuídos às suas obras. Como exemplo, ao ser questionado sobre o andamento do Estudo no 10, Rauta demonstra flexibilidade, ponderando que não considera que o mesmo deva ser "metronômico, matemático, pode ter uma variante, para mais, [ou] para menos” (GOMES, 2018, p. 112).

$\mathrm{Na}$ entrevista final com o compositor perguntamos: 1) quais foram os saldos positivos e negativos da colaboração? 2) obteve satisfação nos resultados alcançados? 3) como foi a interação com a intérprete e, considera que, após a colaboração, obteve novos conhecimentos sobre a composição para violão? Sobre a primeira questão, Rauta afirma que o ponto positivo da colaboração se deu na concretização de seu produto final, ou seja, a partitura com as modificações e digitaçôes registradas no texto musical ${ }^{44}$, as quais a tornaram exequível para a maioria dos instrumentistas: "O saldo positivo foi ter a obra revisada e, portanto, exequível para a maioria dos instrumentistas [...], com essa revisão ampliou-se o leque de possibilidades para mais pessoas executarem o Estudo" (GOMES, 2018, p. 113). Sobre a segunda questão, o compositor afirma que, apesar das modificações realizadas, a ideia original não foi adulterada: "Sim, obtive. Mesmo tendo que abrir mão de certo ponto ou outro, oresultado final soa praticamente a ideia original [...] não aconteceu nada que modificasse plenamente a ideia a

\footnotetext{
${ }^{44}$ Vide a edição do Estudo no 10 digitada e modificada após a colaboração com Rauta no Apêndice 2.
} 
ponto de eu considerar [que] [...] essa não é a minha obra.” (GOMES, 2018, p. 113).

Sobre a interação com o intérprete, o compositor af irma que o formato escolhido para a condução do processo colaborativo o tornou bastante proveitoso:

\begin{abstract}
Nesse quesito [...] achei superinteressante, e uma maneira inteligente de comunicação [...] com vídeos gravados, com propostas, com perguntas para o compositor responder, e depois com contra respostas, ou seja, teve uma interação um pouco mais científica em relação a todo processo de construção. (GOMES, 2018, p. 113).
\end{abstract}

Quanto ao conhecimento advindo do processo, Rauta pontua que, apesar da proximidade com os aspectos técnicos do universo do intérprete, ainda é muito cedo para afirmar que irá escrever para o violão sem eventuais dificuldades:

\footnotetext{
O que eu tinha era uma ideia: 'vou fazer um estudo de tremolo [...] vou passar para a mão esquerda, para a mão direita', mas eu não sabia da possibilidade de execução cem por cento perfeitas daquela ideia, isso eu não tinha consciência, e eu acho que nem terei. Porque eu não sou o instrumentista [...] é muito difícil escrever para violão [...] perfeitamente bem para quem não toca [...] o que eu penso é que, não necessariamente tem que ser totalmente de acordo com a linguagem técnica violonística, o que pode existir, ou acontecer, [é] que uma determinada ideia gere novas possibilidades, e isso amplie também a maneira como se vê o instrumento. (GOMES, 2018, p. 113).
}

A partir dessa análise, interpretamos que o processo colaborativo foi profícuo para o compositor, não apenas pelo resultado obtido, mas também pela forma como foi conduzido. Isso pôde ser notado ao longo do processo, no qual Rauta se mostrou bastante disponível e interessado em realizar a revisão de sua obra de forma colaborativa. Esse fato nos sugere que, por meio do detalhamento de nossas impressóes sobre obra - através da descrição das diversas possibilidades técnicas e do diálogo com violonistas experientes - foi possível demonstrar ao compositor o cuidado que tivemos ao propor as modificaçóes para o Estudo no 10.

Da mesma forma, os comentários feitos por Rauta na primeira, segunda, terceira e sexta etapas, onde sugere ajustes na interpretação e na técnica, enriqueceram minha construção interpretativa e me ajudaram a entrever soluções para problemas técnicos que não haviam sido resolvidos. 


\section{Consideraçõoes Finais}

A pesquisa investigou a resolução de passagens não-idiomáticas através de um processo colaborativo entre compositor e intérprete no Estudo no 10 para violão solo do compositor brasileiro Marcelo Rauta. Ao interpretar o estudo, observei que algumas passagens grafadas eram de difícil ou impossível execução, o que me levou a propor um processo colaborativo com o compositor para aventar alternativas que possibilitassem a execução idiomática do texto musical no instrumento. Nessa observação, parti do princípio de que uma obra idiomática é aquela que proporciona maior aproveitamento das potencialidades instrumentais, refletindo-se tanto na exequibilidade técnica quanto na interpretação musical.

Com a finalidade de identificar passagens do estudo que soavam problemáticas para o violão e evitar que os problemas de execução não fossem interpretação de minhas próprias dificuldades técnicas individuais, propus que três violonistas estudassem as obras sem que essa contivesse a marcação dessas passagens. De posse dessas informaçóes provenientes do contato com os participantes e de minhas observações decorrentes do estudo da obra, identifiquei três tipos de categorias que dificultariam a execução do Estudo no 10 por parte de violonistas. Estas passagens foram classificadas em: 1) passagens não-idiomáticas; 2) passagens de dificuldade técnica extrema; 3) passagens de dificuldade técnica usual.

Após a organização desses dados, iniciamos o processo colaborativo com o compositor, o qual pode ser classificado na modalidade de colaboração interativa de Hayden \& Windsor (2007). Nessa modalidade a pesquisadora exerceu função de intérprete executante e consultora, classificação essa atribuída conforme as funções do intérprete pontuadas por Beal \& Domenici (2014). Nessa fase da obra a mesma já se encontrava finalizada, e por isso, o grau de intervenção do intérprete em relação ao texto musical pode ser considerado moderado, já que o mesmo não compartilha da autoria da obra com o compositor desde o início de sua criação. Com base na bibliografia revisada, compreendemos que a alteridade e a comunicação clara e honesta, abordadas por Domenici (2012a) e Hansen (2016) respectivamente, são fatores indispensáveis para que a interação seja produtiva. Desse modo, objetivando incorporar esses conceitos na reelaboração das passagens não-idiomáticas do Estudo na 10 por meio da colaboração, unimos diferentes recursos de registro e interlocução, tais como: diários 
de estudo, vídeos, fotos, gravaçóes de áudio, entrevista e videoconferências. Sendo assim, percebemos que, ao registrar as sugestôes e comentários em arquivos word, foi possível tanto para mim, enquanto intérprete, quanto para o compositor, revisitar as colocações e comentários diversas vezes, filtrando e detalhando melhor as informações a serem debatidas no processo de colaboração e, principalmente, aproximando a obra do compositor de uma escrita mais idiomática e fluente para o violão.

Destacamos, portanto, a importância das fases e procedimentos adotados no momento anterior à colaboração, onde a participação de outros violonistas foi bastante relevante para a organização de minhas sugestôes de modificação, bem como para que transmitíssemos maior credibilidade à Rauta. Além disso, a entrevista inicial com o compositor nos possibilitou identificar suas concepçôes sobre idiomatismo e colaboração e, desse modo, entrever o melhor direcionamento para o processo colaborativo.

Evidentemente não podemos deixar de considerar que o contato pessoal prévio com Rauta nos proporcionou uma maior naturalidade na proposição das modificações no texto de sua obra. Ainda assim, ressaltamos que o formato empregado para desenvolver o processo colaborativo possibilitou a ambas as partes mediar as expectativas em relação ao texto musical do Estudo no 10 . Por fim, ao compararmos a edição original com a edição elaborada após a colaboração, percebemos que foi possível atingir um resultado técnico e musical idiomático no Estudo no10, sem que a ideia inicial do compositor fosse alterada em sua essência. De fato, o contato com o compositor nos proporcionou uma versão da obra que se aproxima da ideia que o mesmo imaginou sobre como essa poderia soar se tocada no violão, ou seja, o conhecimento de elementos próprios do universo do intérprete é de fundamental importância para que se obtenha o idiomatismo na escrita para violão, e observamos, a partir dessa pesquisa, que a colaboração entre compositores e intérpretes, quando conduzida sob um ponto de vista sistematizado, pode ser um importante viés para que haja contribuiçóes com acréscimos de obras para a literatura violonística brasileira. Como resultado, a pesquisa apresenta, além das discussóes acerca da colaboração e do idiomatismo, uma nova edição da obra com características mais idiomáticas ao instrumento. 


\section{REFERÊNCIAS}

ALVIM, Izabela da Cunha Pavan. Entre estudos e polcas: a propósito do idiomatismo pianístico de Bobuslav Martinu (1890-1959). 2012. Dissertação (Mestrado em Música). Universidade Federal de Minas Gerais (UFMG), Belo Horizonte, 2012.

AZEVEDO, Pedro Santos de. A relação compositor/intérprete: apontamentos históricos, relatos composicionais e estudo de caso na obra o chamado do anjo de Leonardo Martinelli. 2017. Dissertação (Mestrado em Música). Universidade Estadual de Campinas (UNICAMP), Campinas, 2017.

BEAL, Touanda Julia; DOMENICI, Catarina. A colaboração compositor-intérprete: concepçóes e conceitos na ótica de compositores e intérpretes. In: SALÃO DE INICIAÇÃO CIENTÍFICA DA UFRGS, XXVI, 2014, Porto Alegre. XXVI Salão de Iniciação Científica. UFRGS, 2014.

BORÉM, Fausto. Lucípheres de Eduardo Bértola: a colaboração compositor-performer e a escrita idiomática para contrabaixo. Revista OPUS, Rio de Janeiro, v. 5, n. 5, p. 48-75, 1998.

Duo Concertant-Danger Man de Lewis Nielson: aspectos da escrita idiomática para contrabaixo. Per Musi, Belo Horizonte, v.2, p.40-49, 2000.

CAMPBELL, Luciano. O processo colaborativo entre compositor e intérprete em Framefire II, para saxofone e tape, de Luciano Campbell. IN: FESTIVAL LATINO-AMERICANO DE MÚSICA CONTEMPORÂNEA DE PELOTAS, I, 2012, Pelotas. I Festival Latino Americano. Pelotas: Universidade Federal de Pelotas, 2012. p. 01-07.

DOMENICI, Catarina. A Voz do Performer na Música e na Pesquisa. In: SIMPOM-SIMPÓSIO BRASILEIRO DE PÓS-GRADUANDOS EM MÚSICA. II, 2012a, Rio de Janeiro. Anais do II Simpósio do Simpom. Rio de Janeiro: UNIRIO, 2012a. p. 169-182.

His master's voice: a voz do poder e o poder da voz. Revista do Conservatório de Música da UFPel, Pelotas, n.5, p. 65-97, 2012b.

GOMES, Sabrina Souza. A reelaboração de passagens não-idiomáticas do Estudo no 10 para violão solo de Marcelo Rauta por meio da colaboração intérprete-compositor. 2018. Dissertação (Mestrado em Música). Universidade Federal do Rio Grande do Sul, Porto Alegre, 2018.

HANSEN, Micah. Perspectives of the interaction between composer, student performer, and music educator: commissioned works in selected school ensembles. 2016, 175 fl. Dissertação (Mestrado em Música). Boston University, Boston, 2016.

HAYDEN, Sam; WINDSOR, Luke. Collaboration and the composer: Case studies from the end of the 20th century. Tempo, p. 28-39, 2007.

INGARDEN, Roman. The Work of Music and the Problem of its Identity. 1986. Berkeley: University of California Press, 1961.

KREUTZ, Thiago de Campos. A música para violão solo de Edino Krieger: um estudo do idiomatismo técnico-instrumental e processos composicionais. 2014. Dissertação (Mestrado em Música). Universidade Federal de Goiânia, Goiânia, 2014. 
LÓPEZ-CANO, Rubén; SAN CRISTÓBAL, Úrsula. Investigación artística en música: problemas, métodos, paradigmas, experiencias y modelos. Barcelona: Fonca-Esmuc, 2014.

MADEIRA, Bruno; SCARDUELLI, Fabio. Ampliação da técnica violonística de mão esquerda: em estudo sobre a pestana. Per Musi, Belo Horizonte, n. 27, p. 182-188, 2013.

MARQUES, Kleber Dessoles. Técnicas Estendidas para Saxofone em obras compostas por meio de colaboração compositor-intérprete. 2015. Dissertação (Mestrado em Música). Universidade Federal do Rio Grande do Norte, Natal, 2015.

PEREIRA, Marcelo Fernandes; GLOEDEN, Edelton. Apontamentos sobre o idiomatismo na escrita violonística. In: CONGRESSO DA ASSOCIAÇÃO NACIONAL DE PESQUISA E PÓSGRADUAÇÃO EM MÚSICA, XXII. 2012, João Pessoa. Anais do XXII Congresso da Anppom. João Pessoa, UFPB, 2012. p. 526-533.

RADICCHI, Joana; ASSIS, Ana Cláudia. Inflexões para flauta solo: um estudo sobre a colaboração compositor-intérprete. In: CONGRESSO DA ASSOCIAÇÃO BRASILEIRA DE PERFORMANCE MUSICAL. II, 2014, Vitória. Anais do II Congresso da Abrapem. Vitória: UFESFAMES, 2014. p. 202-210.

RAMOS, Pamela dos Santos. A Colaboração compositor-intérprete na construção de uma interpretação para a peça Round About Debussy de Flávio Oliveira. 2013. Dissertação (Mestrado em Música). Universidade Federal do Rio Grande do Sul, Porto Alegre, 2013.

RAUTA, Marcelo. Estudo no 10. Vitória, Edição própria, 2018. Partitura, 3 páginas. Violão Solo.

SCARDUELLI, Fábio. A Obra Para Violão Solo de Almeida Prado. 2007. Dissertação (Mestrado em Música). Universidade de Estadual de Campinas, Campinas, 2007.

SCARDUELLI, Fabio; RIBEIRO, Felipe de Almeida. Criação musical colaborativa: o processo de escrita e performance de Melancoli[r]a para violão solo. In: XXVI Congresso da Associação Nacional de Pesquisa e Pós-Graduação em Música. XXVI, 2016. Anais do XXVI Congresso da Anppom. Belo Horizonte: UFMG, 2016. p. 01-07.

SILVA, Anderson Afonso. Música para trompa e Sixxen, de Estércio Marquez Cunha: resultados sonoros na colaboração entre compositor e intérprete. 2017. Dissertação (Mestrado em Música). Universidade Federal de Goiânia, Goiânia, 2017.

SILVA, Dario Rodrigues. A obra pianistica de Marisa Rezende: processo de construção da performance através da interação entre intérprete e compositora. 2015. Dissertação (Mestrado em Música), Universidade Federal do Rio Grande do Sul, Porto Alegre, 2015.

SIMÕES, Renan Colombo. O processo de revisão da peça Aberturinhazinha, para violão solo, de Marcelo Rauta. I SIMPÓSIO ACADÊMICO DE VIOLÃO DA EMBAP. Curitiba: EMBAP, 2016a, p. 251-260.

. O processo de revisão de três movimentos da Suíte Chaves, para violão solo, de Marcelo Rauta. IN: CONGRESSO DA ABRAPEM, IV, 2016, Campinas. Anais do IV Congresso da Associação Brasileira de Performance Musical. Campinas: UNICAMP, 2016 b. p. 251-260.

TULLIO, Eduardo Fraga. O Idiomatismo nas composições para percussão de Luiz D’Anunciação, Ney Rosauro e Fernando Iazzetta: análise, edição e performance das obras selecionadas. IN: 
CONGRESSO DA ANPPOM, XV, 2005, Rio de Janeiro. Anais do XV Congresso da ANPPOM. Rio de Janeiro: UFRJ, 2005. p. 296-303.

VIEIRA, Márlou Peruzzolo. Composer and Performer in Collaboration: Interactive Processes Involving non-guitarists Composers and Guitarists. In: CONFERENCE OF THE EUROPEAN SOCIETY FOR THE COGNITIVE SCIENCES OF MUSIC-ESCOM, IX, 2015, Manchester. IX Conference of European Society for Cognitive Sciences of Music. Escom, 2015. p. 816-825.

. The collaborative process from the performer's perspective: a case study of non-guitarist composers. 2017. Tese (Doutorado em música). Universidade de Aveiro, Aveiro, 2017.

\section{SOBRE OS AUTORES}

Sabrina Souza Gomes: doutoranda e Mestre em Música (Práticas Interpretativas - Violão) pela UFRGS, e Bacharel em Música (Habilitação - Violão) pela FAMES, tem atividade artística como solista e integra o Duo Capixaba de Violóes e o grupo de performance, colaboração e criação musical Coletivo NSLO. Atuou como professora nas instituições UERN e UFRN, e tem realizado atividades de pesquisa e performance no âmbito da colaboração intérprete-compositor. ORCID: https://orcid.org/0000-0001-8089-380. E-mail: sabrinasouzagomes@hotmail.com.

Leonardo Loureiro Winter: professor Associado IV de Flauta Transversal na UFRGS. Orientador permanente do Programa de Pós-Graduação em Música da UFRGS: Mestrado e Doutorado em Práticas Interpretativas. Doutor em Execução Musical (Flauta) pela UFBA tem publicado artigos em revistas especializadas enfocando o repertório brasileiro para flauta, análise, construção interpretativa, performance e ansiedade na performance musical. Tem procurado conciliar intensa atividade artística como camerista e solista com suas atividades acadêmicas. ORCID: https://orcid.org/00000001-6238-7704. E-mail: leonardo.winter@ufrgs.br. 


\section{APÊNDICE}

Apêndice 1 - Edição original do Estudo no 10 para violão solo de Marcelo Rauta

$$
\begin{gathered}
\text { Estudo } n^{0} 10 \\
(2015)
\end{gathered}
$$
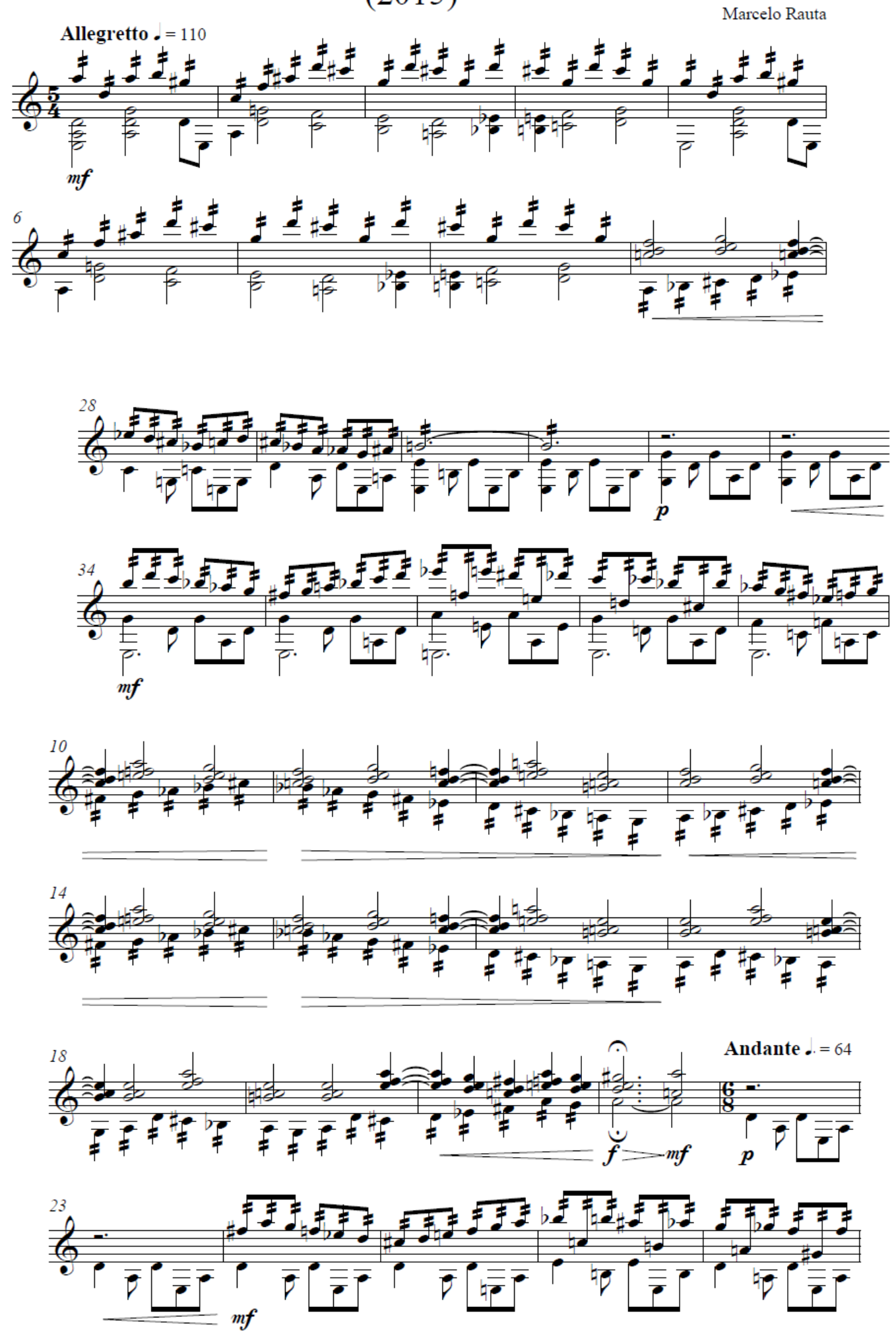

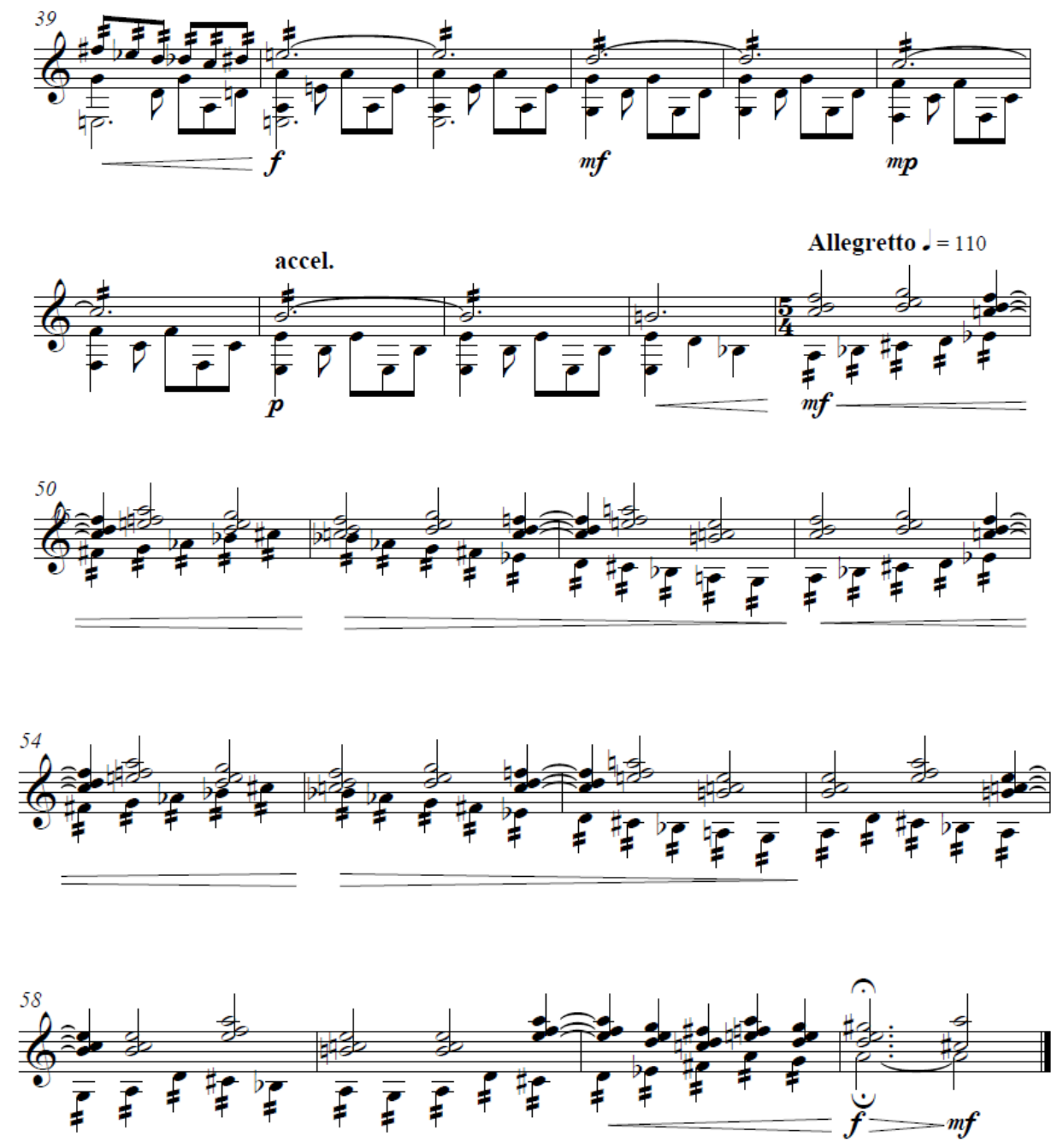

Apêndice 2 - Edição modificada e digitada após do Estudo no 10 para violão solo após a colaboração com Marcelo Rauta

\section{Estudo nº 10}

Marcelo Rauta Digitaçăo de Sabrina Soura
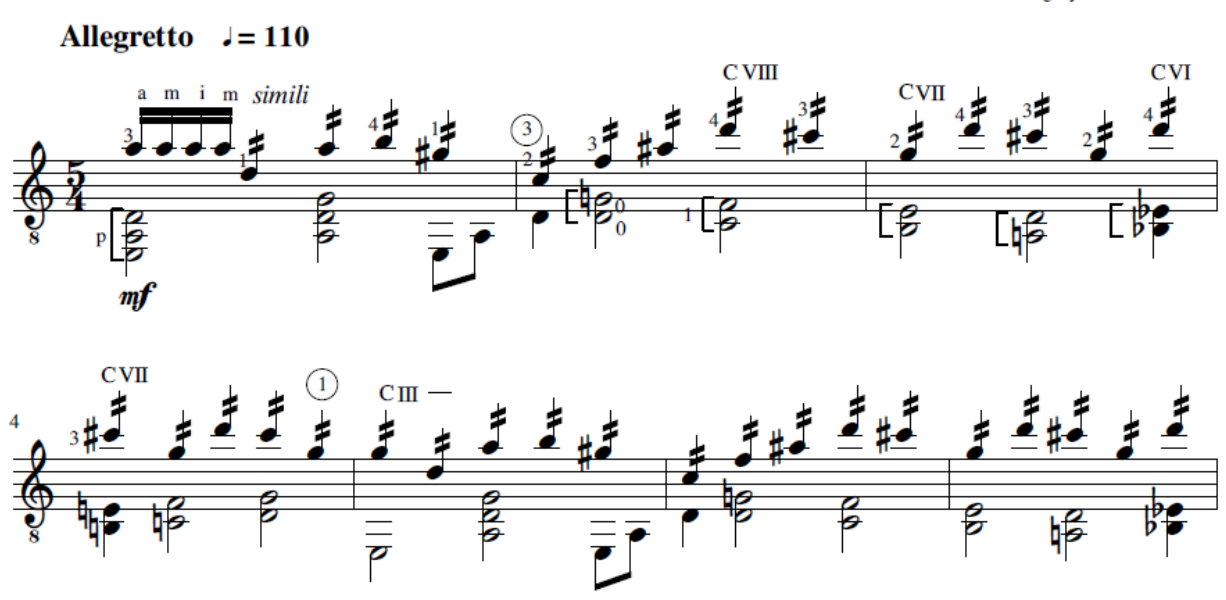

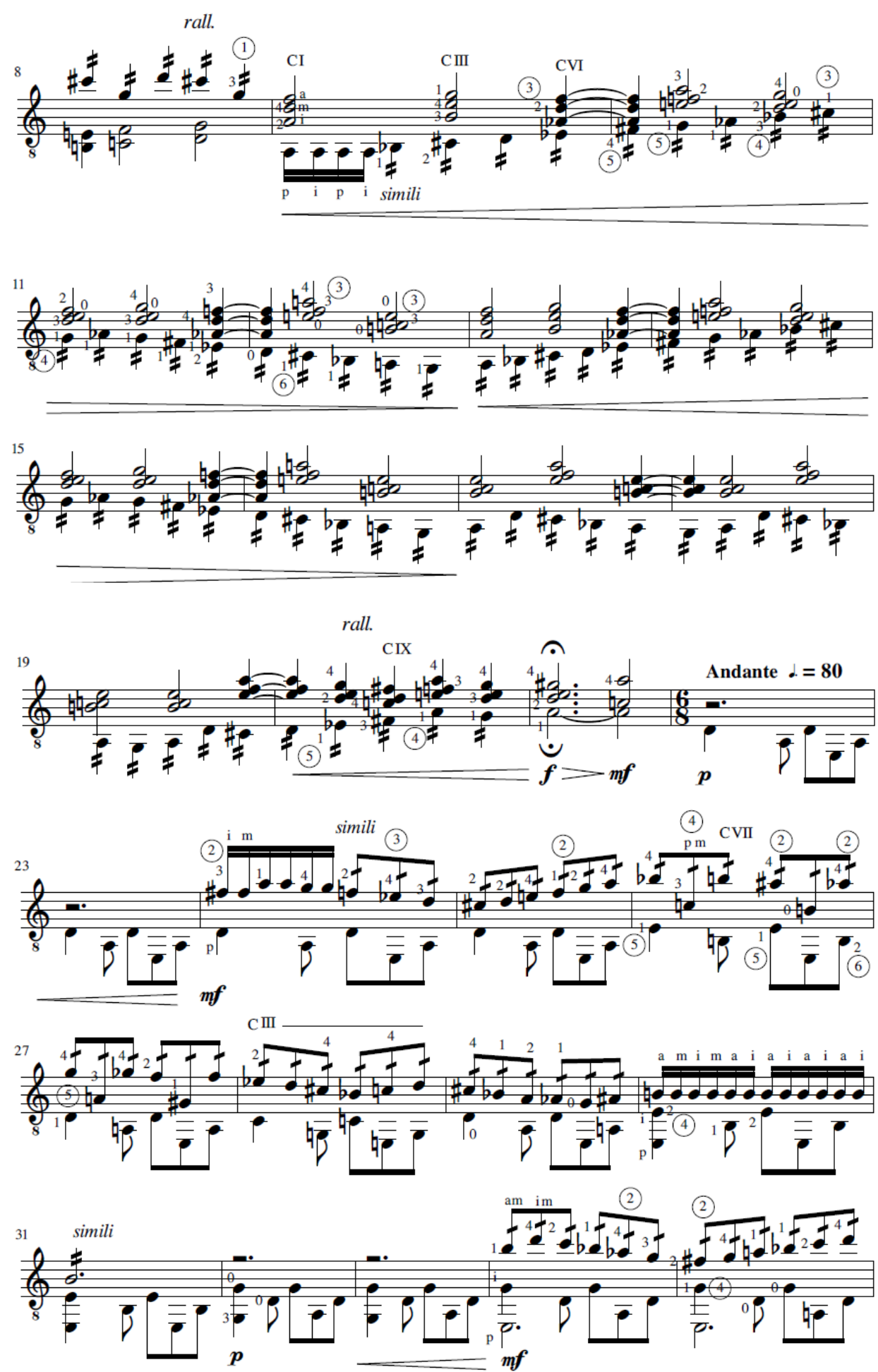

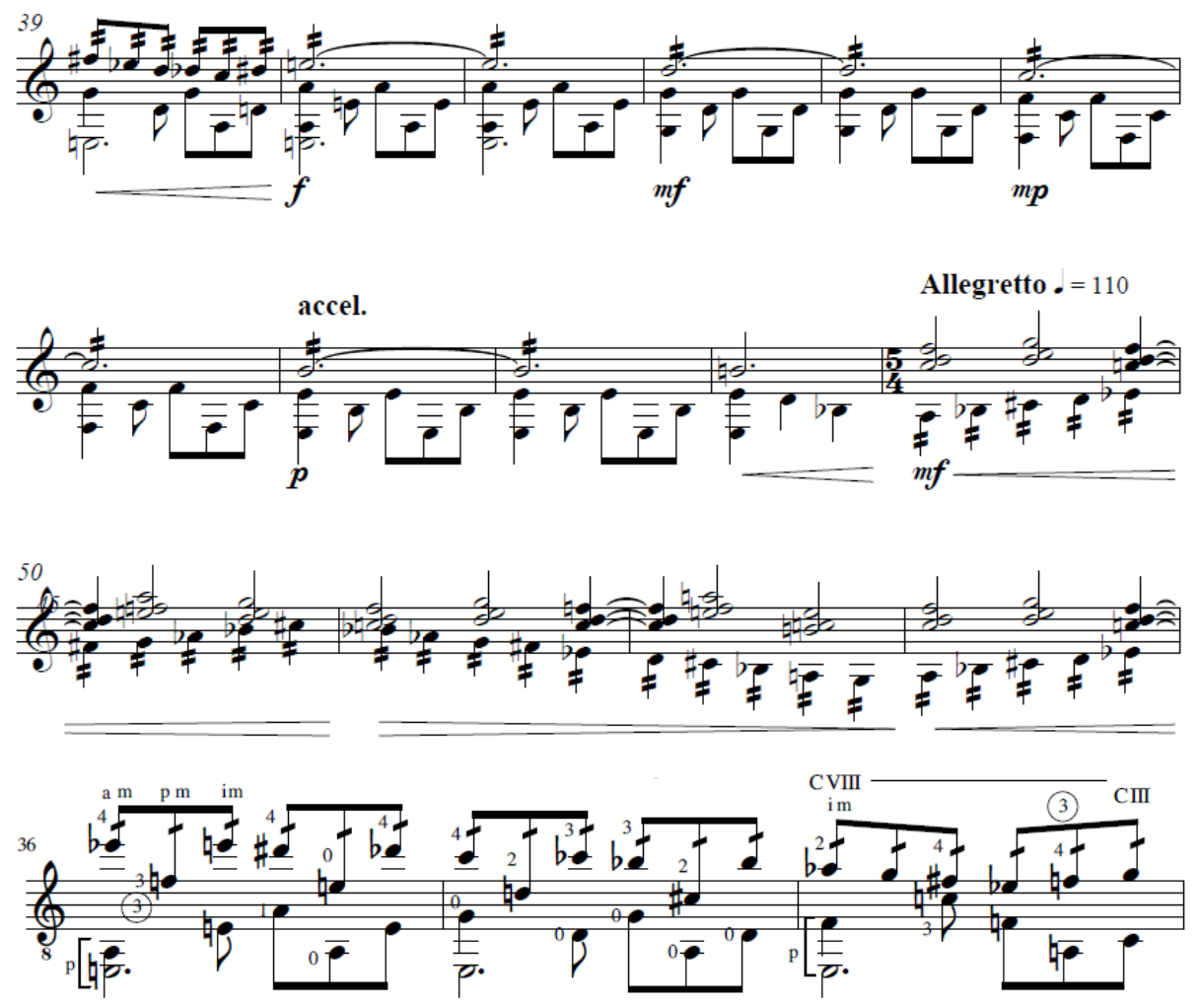

(2)
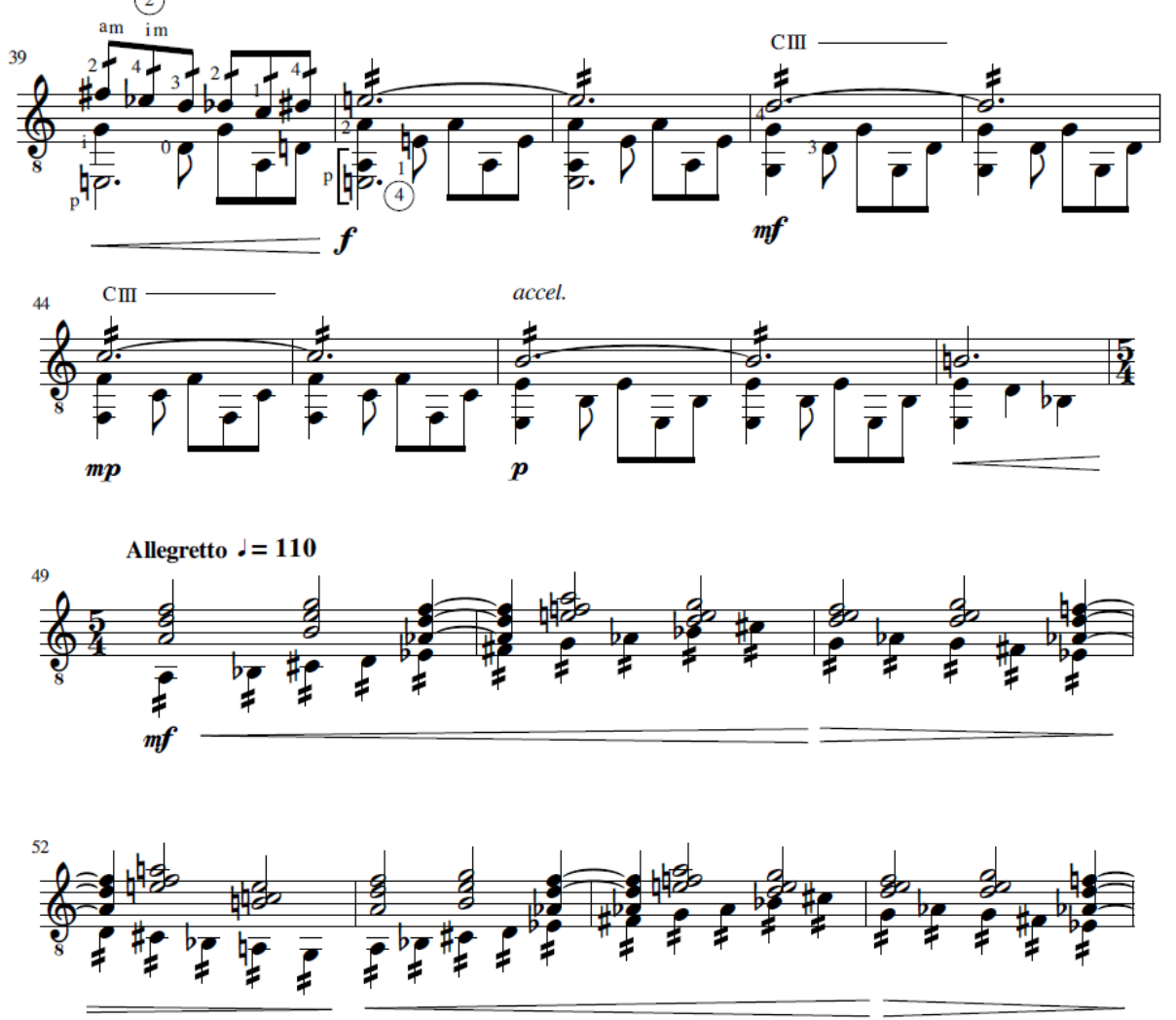

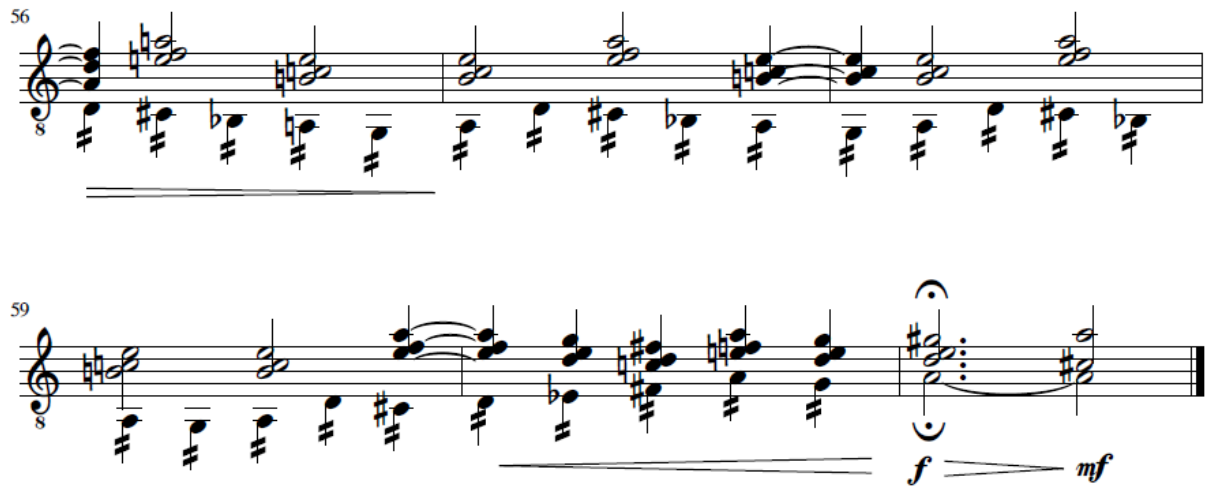